\title{
Examination of different fungicides against Macrophomina phaseolina in laboratory conditions
}

Kitti Csüllög ${ }^{1,2}$ - Gábor Tarcali ${ }^{1}$

${ }^{1}$ University of Debrecen Faculty of Agricultural and Food Sciences and Environmental Management Plant Protection Institute, Böszörményi street 138, 4032 Debrecen, Hungary

${ }^{2}$ University of Debrecen, Kerpely Kálmán Doctoral School, Böszörményi street 138, 4032 Debrecen, Hungary

kitticsullog@gmail.com

\section{SUMMARY}

\begin{abstract}
In Hungary, sunflower is the third most important arable crop, which has a lot of pathogenic fungi. One of these fungi is the Macrophomina phaseolina, which is a well-known fungus in all over the world, since this pathogen has more than 700 host plants. In Hungary, several host plants can be found as well. The M. phaseolina produces microsclerotia, which can survive in the soil and residues for almost 10 years. For now, there is no efficient treatment against this pathogen because of this fungus, since it is extremely resistant and cannot be destroyed easily. The only effective treatment against the fungus is genetic defence. In this study, three different fungicides were tested in vitro against the fungus. The Mirage (prochloraz) seemed to be the most effective fungicide as it completely arrested the hyphal growth. In contrast, the Amistar Xtra (azoxystrobin and ciprochonazol) has only a minor effect on the growth of M. phaseolina. Thirdly, the Retengo (pyrachlostrobin) arrested the hyhpal growth of the fungus with $71 \%$ at 100 ppm, in other words, the use of this fungicide seems promising.
\end{abstract}

Keywords: Macrophomina phaseolina, in vitro, fungicide, azoxystrobin, ciprochonazol, prochloraz, pyraclostrobin

\section{INTRODUCTION}

Sunflower (Helianthus annuus) is the third most important field crop in Hungary and it is grown on more than 500.000 hectares. This plant has a number of pathogenic fungi: Plasmopara halstedii, Phoma macdonaldi, Diaporthe helianthi, Alternaria sp. Septoria helianthi, Sclerotinia sclerotiorum and Macrophomina phaseolina. These fungi cause huge damage to the health of the sunflower crop. In Hungary, Békési (1970) was the first who described the $M$. phaseolina on sunflowers. This fungus is hosted by approximately 700 species (Békési et al., 2014).

The pathogen was identified in Zea mays (Vörös and Manninger, 1973), Glycine max (Érsek, 1979). From 1987 to 1991 Simay found this fungus in Solanum tuberosum, Helianthus tuberosus, Phaseolus vulgaris, Vicia faba, Allium sativum, moreover it was also identified in Beta vulgaris (Koppányi, 1993), Cannabis sativa, Valeriana officinalis (Simay and Kadlicskó, 1993), Capsicum annuum (Fischl et al., 1995), Citrullus lanatus (Békési et al., 1995) Prunus armeniaca (Vajna and Rozsnyai, 1995) and Picea pungens (Fischl et al., 2008). It has 2 anamorph forms. The name of the pycnidia form, which constitute conidiophores $M$. phaseolina. Another form is Rhizoctonia bataticola constitute microsclerotia. The fungus constitutes microsclerotia both on and within the stem. Pycnidia are usually in host tissue.

Taxonomic Description of Macrophomina phaseolina (Wheeler, 1975)

Division Eumycota

Sub Division Deuteromycotina

Class Coelomycetes

Order Sphaeropsidales

Family Sphaeropsidaceae

Genus Macrophomina

Species phaseolina
M. phaseolina is primarily a seed, soil and stubble borne pathogen. This fungus causes charcoal rot, root rot and seedling blight in young plants; and in adult plants shows wilting, premature dying and loss of vigor. On sunflower after flowering this fungus cause early maturing. If the temperature is high and there is a high level of drought around flowering time, the symptoms are dramatic and progressive. After flowering, the lower stem and top of the taproot will show grey and black discoloration, and also shredding of the plant tissue. The epidermis is usually removed and in the stem there are numerous microsclerotia. (Sinclair, 1982; Yang and Owen, 1982; Hoes, 1985; Kolte, 1985).

The oil content is higher when infected with $M$. Phaseolina than in the healthy sunflower. The head weight and diameter are less in infected sunflowers when compared with healthy sunflowers. (Raut, 1983; Kolte, 1985). The microsclerotia can survive in the soil almost 10 years.

There is no effective treatment against the pathogen. Békési (2007) claimed that dressing and the late showing can provide protection as the fungus probably prefer early and dense showing. However, the most effective solution would be the development of genetic protection against the pathogen. Further protective methods could include rotation crop. However, due the polyphagic trait of M. phaseolina wide host range related to the fungus, the establishment of crop rotation is difficult not only in Hungary, but also all over the world. According to Ndiaye et al. (2008) the amount of microsclerotia in the soil decrease if Panicum miliaceum or Digitaria sp. are integrated in the crop rotation. Kending et al. (2000) claimed that appropriate amount of water supply can push back the amount of microslerotium in soil. There are other biological protection methods against the $M$. phaseolina as well: Aspergillus sp. (Eswaran and Mishra, 2004), Trichoderma sp. (Dinakaran et al., 1995; Prashanthi et al., 2000), pl. Actinomycetes sp. 
(Herbar et al., 1991), Pseudomonas sp. (Kavitha et al., 2005) and Bacillus subtilis (Siddiqui and Mahmood, 1993).

\section{MATERIALS AND METHODS}

We tested 3 different pesticides at 4 different concentrations for the growth mycelial and sclerotial formation of this pathogen by using a poisoned media technique.

Amistar Xtra (200 $\mathrm{g} \mathrm{L}^{-1}$ azoxystrobin $+80 \mathrm{~g} \mathrm{~L}^{-1}$ ciprochonazol, $1 \mathrm{~L} \mathrm{ha}^{-1}$ ): ,Both active ingredients act as an inhibitor of mitochondria respiration by disrupting the energy cycle within the fungus and interrupting the biosynthesis of ergosterol. This interferes in the fungal life cycle mainly during spore germination, infection and hyphen growth. Both active ingredients are transported acropetally and translaminary in the xylem and therefore gradual uptake in to the leaves of the plants." (I1). Retengo (200 $\mathrm{g} \mathrm{L}^{-1}$ pyraclostrobin $1 \mathrm{~L} \mathrm{ha}^{-1}$ ): „Pyraclostrobin has a sustained inhibiting effect on spore germination, the formation of infection structures, mycelial growth and sporulation of harmful fungus. The fungicide is taken up via the leaves and shows primarily locally systemic and translaminar activity. In small volumes, the active ingredient is transferred through the plant via the sap." (I2). Mirage

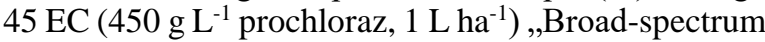
with protectant and eradicant properties. Disrupts membrane function." (I3).

We made a number of stock solutions with various concentrations of fungicides, testing at $10 \mathrm{ppm}, 20$ ppm, $50 \mathrm{ppm}$ and $100 \mathrm{ppm}$. On each plates $1 \mathrm{ml}$ stock solutions was pipetted and mixed with $20 \mathrm{ml} 50^{\circ}$ (liquid) media. After the solidification of media, $0.5 \mathrm{~cm}$ diameter M. phaseolina disc was placed into the centre of poisoned plates. These discs were taken from 7 days old pure culture. The poisoned mediums with $0.5 \mathrm{~mm}$ diameter mycelial discs were incubated under dark condition at $25 \pm 1{ }^{\circ} \mathrm{C}$ for 6 days. We used 130 Petri dishes (10 dishes/ppm). Fungicide was not added to control plates. The linear growth of $M$. phaseolina colonies was measured on the third and on the sixth day. The measurement of the colonies was two different angels $(\mathrm{mm})$ and after the average values calculated.

The per cent inhibition of growth of M. phaseolina was calculated using the following formula (Vincent, 1947):

$$
I=\frac{C-T}{C} \times 100
$$

Where, $\mathrm{I}=$ Per cent inhibition

$\mathrm{C}=$ Colony diameter in control $(\mathrm{mm})$

$\mathrm{T}=$ Colony diameter in respective treatment $(\mathrm{mm})$

\section{RESULTS AND DISCUSSION}

The three tested fungicides produced different results (Table 1). The result of the first measurement was the Mirage (prochloraz) completely arrested the hyphal growth (Figure 1, Figure 2). The M. phaseolina did not produce form of microsclerotia just only in control plates. The Amistar Xtra did not arrest the fungus. The Retengo arrested the pathogen but not completely. The control at the first measurement produce microsclerotia and the hyphal system of the pathogen completely overran the media.

The M. phaseolina hyhpal growth at first measurement

\begin{tabular}{lcccc}
\hline & $\mathbf{1 0} \mathbf{~ p p m}$ & $\mathbf{2 0} \mathbf{~ p p m}$ & $\mathbf{5 0} \mathbf{~ p p m}$ & $\mathbf{1 0 0} \mathbf{~ p p m}$ \\
\hline Amistar Xtra Mycelia (mm) & 52.8 & 50.5 & 44 & 38.1 \\
Mirage Mycelia (mm) & 0 & 0 & 0 & 0 \\
Retengo (mm) Mycelia & 36.5 & 30.1 & 25 & 22 \\
Control Mycelia (mm) & & 90 & \\
Control Mycrosclerotia (mm) & & 66.72 & \\
\hline
\end{tabular}

Figure 1: The hyphal growth in 10 and $20 \mathrm{ppm}$ at the first measurement

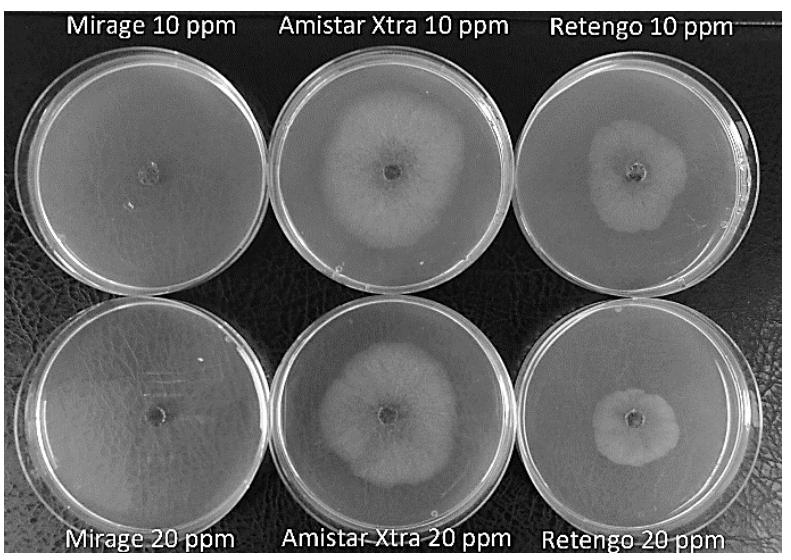

Figure 2: The hyphal growth in $\mathbf{5 0}$ and $\mathbf{1 0 0} \mathbf{~ p p m}$ at the first measurement

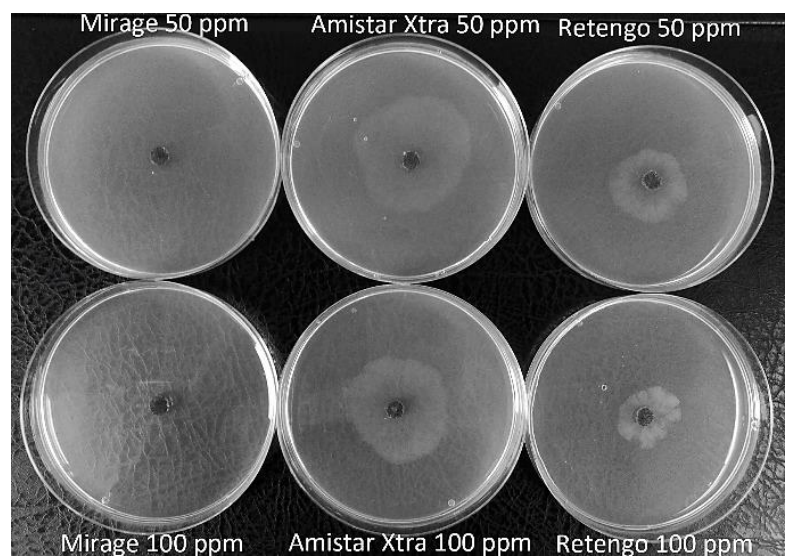


At the second measurement the M. phaseolina produced microsclerotia (Table 2). The hyphal system of fungus overran the entire media at $10 \mathrm{ppm}, 20 \mathrm{ppm}$ and $50 \mathrm{ppm}$ on the Amistar Xtra poisoned media (Figure 3, Figure 4). At $100 \mathrm{ppm}$ the hyphal system of pathogen grew only $70.5 \mathrm{~mm}$. Similarly to the first measurement the prochloraz did not arrest any hyphal and microsclerotial growth of the pathogen. Due to the influence of Retengo, the growth of $M$. phaseolina fungus was observed on each ppm treatment, however, the rate of the growth did not exceed the efficiency of Amistar Xtra, because in the case of treatment with the Amistar Xtra fungicide, the growth of the hyphal and microsclerotia was even more intense.

The M. phaseolina hyhpal growth at second measurement

\begin{tabular}{lcccc}
\hline & $\mathbf{1 0} \mathbf{~ p p m}$ & $\mathbf{2 0} \mathbf{~ p p m}$ & $\mathbf{5 0} \mathbf{~ p p m}$ & $\mathbf{1 0 0} \mathbf{~ p p m}$ \\
\hline Amistar Xtra (mm) Mycelia & 90 & 90 & 90 & 70.5 \\
Amistar Xtra (mm) Microsclerotia & 65.1 & 57.2 & 52.6 & 46.6 \\
Mirage (mm) Mycelia & 0 & 0 & 0 & 0 \\
Mirage (mm) Microsclerotia & 0 & 0 & 0 & 0 \\
Retengo (mm) Mycelia & 58.6 & 39.6 & 31.8 & 25.8 \\
Retengo (mm) Microsclerotia & 37.1 & 29.1 & & 22.6 \\
\hline Control Mycelia (mm) & & $90 \mathrm{~mm}$ & \\
Control Mycrosclerotia (mm) & & $90 \mathrm{~mm}$ & \\
\hline
\end{tabular}

Figure 3: The hyphal and microsclerotia growth in poisoned media with pyraclostrobin

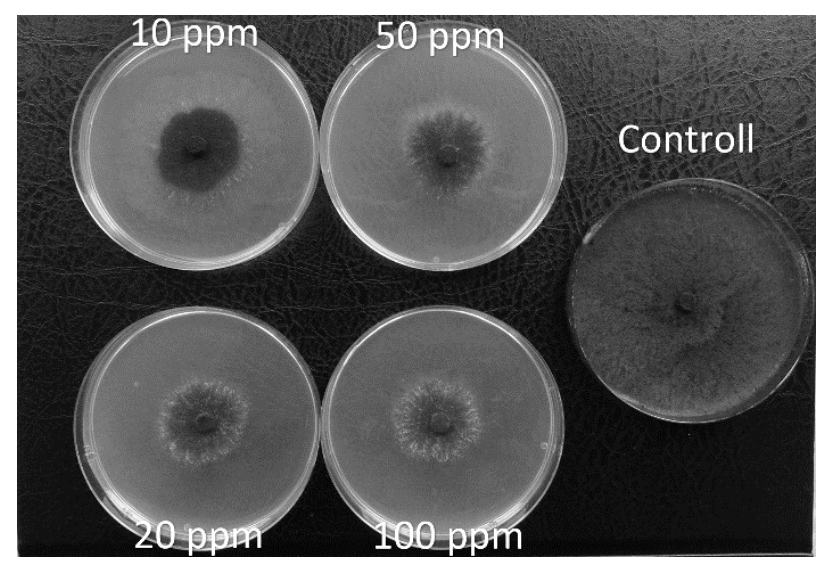

The following table shows the first measurement of the per cent inhibition of growth of $M$. phaseolina (Table 3). The Mirage was the most effective fungicide. At 100 ppm the pyraclostrobin arrested $75 \%$ the hyphal growth of fungus, while the Amistar Xtra arrested only $58 \%$.

At the second measurement the prochloraz did not allow growth of the pathogen, while the Amistar Xtra
Figure 4: The hyphal and microsclerotia growth in poisoned media with azoxystrobin and ciprochonazol

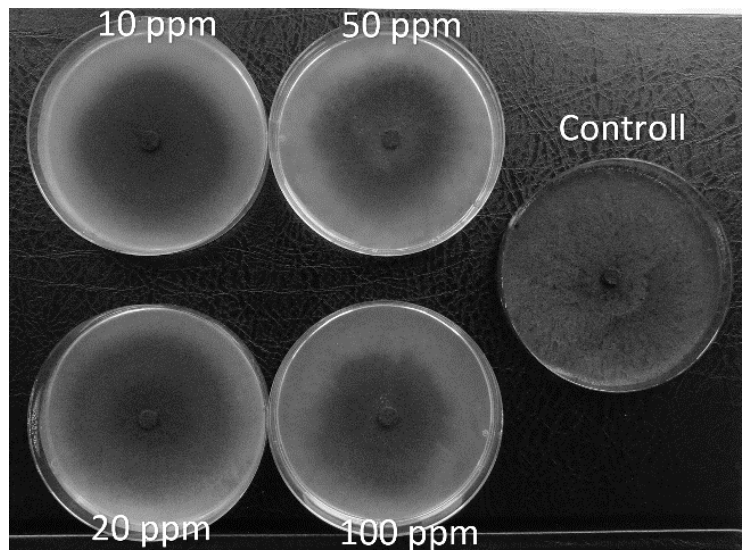

and the pyraclostrobin did allow it (Table 4). The hyhpal system completely overran the media at $10 \mathrm{ppm}$, $20 \mathrm{ppm}$ and $50 \mathrm{ppm}$ poisoned media with Amistar Xtra. The pathogen produced microsclerotia form at every concentration of Amistar Xtra and Retengo. At 100 ppm the microslerotia form was arrested supremely.

At the first measurement the inhibition of the growth in percentage

\begin{tabular}{lcccc}
\hline & $\mathbf{1 0} \mathbf{~ p p m}$ & $\mathbf{2 0} \mathbf{~ p p m}$ & $\mathbf{5 0} \mathbf{~ p p m}$ & $\mathbf{1 0 0} \mathbf{~ p p m}$ \\
\hline Amistar Xtra (\%) & 42 & 44 & 52 & 58 \\
Mirage (\%) & 100 & 100 & 100 & 100 \\
Retengo (\%) & 59 & 67 & 72 & 75 \\
\hline
\end{tabular}


At the second measurement the inhibition of the growth in percentage

\begin{tabular}{lcccc}
\hline & $\mathbf{1 0} \mathbf{~ p p m}$ & $\mathbf{2 0} \mathbf{~ p p m}$ & $\mathbf{5 0} \mathbf{~ p p m}$ & $\mathbf{1 0 0} \mathbf{~ p p m}$ \\
\hline Amistar Xtra Mycelia (\%) & 0 & 0 & 0 & 18 \\
Amistar Xtra Microsclerotia (\%) & 28 & 36 & 42 & 49 \\
Mirage Mycelia (\%) & 100 & 100 & 100 & 100 \\
Mirage Microsclerotia (\%) & 100 & 100 & 100 & 100 \\
Retengo Mycelia (\%) & 35 & 56 & 62 & 71 \\
Retengo Microsclerotia (\%) & 58 & 68 & 67 & 75 \\
\hline
\end{tabular}

\section{CONCLUSIONS}

M. phaseolina fungus is a prevalent pathogen worldwide, including Hungary. Unfortunately, there is no effective treatment against this fungus. In the field there are no effective fungicides that farmers can use against the pathogen. In Hungary, there are no sunflower species, which are resistant to this fungus. In this study we tested 3 fungicides and only the prochloraz was be able to arrest the hyphal and microsclerotial growth. Conversely the azoxystrobin and ciprochonazol (Amistar Xtra) cannot arrested the hyphal and microsclerotic growth enough. The pyraclostrobin had a moderate effect. The $M$. phaseolina could grow on the poisoned media with pyraclostrobin, but not too much. At present, the only reliable treatment is the genetic protection.

\section{REFERENCES}

Békési, P. (2007): A napraforgó növénykórtani állapota 2007-ben. Gyakorlati Agrofórum, 18 (11): 17-19.

Békési, P.-Szani, Sz.-Zalka, A. (1995): A Macrophomina phaseolina (Tassi) Goid. hazai előfordulása dinnyén. Integrált termesztés a kertészetben (16.). Budapest, 107.

Békési, P.-Csöndes, I--Kadlicskó, S. (2014): Veszélyes növénybetegségek (II. 9.). A napraforgó hamuszürke szárkorhadása. Agrofórum 25. 6. 34-37.

Dhingra, O.B.-Sinclair, J.B. (1978): Biology and pathology of Macrophomina phaseolina. Universidade Federal de Viscosa, Brazil, P. 166.

Dinakaran, D.-Ramakrishnan, G.-Sridhar, R.-Jeyarajan, R. (1995): Management of sesamum root rot with biocontrol agents. Journal of Oilseeds Research, 12 (2): 262-263.

Érsek, T. (1979b): Occurence of charcoal rot and anthracnose of soybeans in Hungary. Acta Phytopathologica, 14: 17-21.

Eswaran, A.-Mishra, R. (2004): Mycoparasitic potential and variabilitity of Aspergillus spp. to manage dry root rot of blackgram (Vigna mungo L.). Indian Journal of Plant Protection, 32 (2): 89-92.

Fischl, G.-Kadlicskó S.- ifj. Kovács, J. (1995): A Macrophomina phaseolina (Tassi) Goid. okozta tőhervadás paprikán. Növényvédelem, 31 (12): 589-592.

Fischl, G.-Csöndes, I.-Kadlicskó, S.-Józsa, A. (2008): Az ezüstfenyő (Pinus pungens ENGELM.) vörösödését és pusztulását okozó tényezők vizsgálata. Növényvédelem, 44 (8): 401-402.

Herbar, P.-Berge, O.-Heulin, T.-Singh, S.P. (1991): Bacteria antagonists of sunflower (Helianthus annuиs L.) fungal pathogens. Plant and Soil, 133 (1): 131-140.

Hoes, J.A. (1985): Macrophomina phaseolina causal agent of charcoal rot of sunflower and other crops.

I1: https://www.syngenta.co.ke/product/crop-protection/fungicides/ amistar-xtra

I2: https://agriculture.basf.com/en/Crop-Protection/Retengo-Plus.html I3: https://sitem.herts.ac.uk/aeru/ppdb/en/Reports/536.htm
Kavitha, K.-Mathiyazhagan, S.-Sendhilvel, V.-Nakkeeran, S.Chandrasekar, G.-Fernando, W.G.D. (2005): Broad spectrum action of phenazine against active and dormant structures of fungal pathogens and root knot nematode. Archives of Phytopathology and Plant Protection, 38 (1): 69-76.

Kendig, S.R.-Rupe, J.C.-Scott, H.D. (2000): Effect of irrigation and soil water stress on densities of Macrophomina phaseolina in soil and roots of two soybean cultivars. Plant Disease, 84 (8): 895-900.

Kolte, S.J. (1985): Sunflower diseases of annual oilseed crops, Vol. III, CRC Press, Inc. Boca Raton, Florida, P. 33-44.

Koppányi, M.-Nagy, J.-Zsembery, S.-Bódis， Z. (1993): Új hervadásos betegség cukorrépában. Gyakorlati Agrofórum, 7: 41. Agriculture Research Station, Modren Manitoba, Canada.

Ndiaye, M.-Termoshuizen, A.J.-van Bruggen, A.H.C. (2008): Effect of rotation of cowpea (Vigna unguiculata) with fonio (Digitaria exilis) and millet (Pennisetum glaucum) on Macrophomina phaseolina densities and cowpea yield. African Journal of Agricultural Research, 3 (1): 37-43.

Siddiqui, Z.A.-Mahmood, I. (1993): Biological control of Meloidogyne incognita race 3 and Macrophomina phaseolina by Paecilomyces lilacinus and Bacillus subtilis alone and in combination on chickpea. Fundamental and Applied Nematology, 16 (3): 215-218.

Simay, E.I. (1987): A Macrophomina phaseolina (Tassi) Goid. három új gazdanövénye Magyarországon. Növénytermelés, 36 : 91-96.

Simay, E.I. (1990): Adatok a Macrophomina phaseolina (Tassi) Goid. növényköréhez Magyarországon. Növénytermelés, 39: 23-26.

Simay, E.I. (1991a): A Macrophomina phaseolina (Tassi) Goid. előfordulása dísznövényeken. 37. Növényvédelmi Tudományos Napok, Budapest. Összefoglaló, 111.

Simay, E.I. (1991b): A máriatövis (Silybium marianum (L.) Gaertn. hervadásos betegsége és gyökérrothadása. 37. Növényvédelmi Tudományos Napok, Budapest. Összefoglaló, 112. 
Simay, E.I.-Kadlicskó, S. (1993): A Macrophomina phaseolina (Tassi) Goidanich újabb gazdanövényei Magyarországon. Növényvédelem, 29 (1-2): 27-28.

Sinclair, J.B. (1982): Compendium of Soybean disease. $2^{\text {nd }}$ Ed. by American Phytopathology Society, St. Paul, Minnesota, USA.

Prashanthi, S.K.-Kulkarni, S.-Anahosur, K.H. (2000): Management of safflower root rot caused by Rhizoctonia bataticola by antagonistic microorganisms. Plant Disease Research, 15 (2): $146-150$.

Raut, J.G. (1985): Effect of charcoal rot caused by Macrophomina phaseolina on sunflower plant. Indian Phytopathology 38: 245246.

Vajna, L.-Rozsnyai, Zs. (1995): Macrophomina phaseolina (Tassi) Goid. és a Diaporthe eres Nitschke, mint a fiatal kajszifák elhalásában szerepet játszó gombák Magyarországon. Növényvédelem, 31 (2): 81-83.
Vincent, J.M. (1947): Distortion of fungal hyphae in the presence of certain inhibitor. Nature, 159-850.

Vörös, J.-Manninger, I. (1973): A Macrophomina phaseolina (Tassi) Goid. előfordulása kukoricán, Magyarországon. Növényvédelem, 9: 193-195.

Wheeler, H. (1975): Plant pathogenesis. Academic, Press, New York and London, 2-3.

Yang, S.M.-Owen, D.F. (1982): Symptomology and detection of Macrophomina phaseolina in sunflower plants parasitized by Cylendrocopturus adspersus larvae. Phytopathology 72: 819821. 
